\title{
Ahmadinejad's Legacy
}

\section{Jahangir Amuzegar}

Dr. Amuzegar served the prerevolutionary government of Iran as minister of commerce, minister of finance and ambassador-at-large. He was on the Executive Board of the International Monetary Fund, representing Iran and several other member countries between 1974 and 1980. He has taught at UCLA, the University of Michigan, Michigan State University, the University of Maryland, American University and Johns Hopkins SAIS. He is the author of seven books and more than 100 articles on Iran, oil, OPEC and economic development.

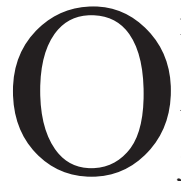

n August 3, 2013, the controversial and crisis-ridden eight-year tenure of President Ahmadinejad came to an end - leaving a sad legacy behind. This review intends to trace this legacy to its major causes.

Of the six politicians who served as president of the Islamic Republic between 1979 and 2013, none has been so mercilessly vilified by a multitude of his detractors, or so admiringly praised by his worshipful friends and acolytes, as Mahmoud Ahmadinejad. There is also no doubt that he has been both patriotic and well-meaning. What he did to the country and the economy clearly reflected the best of his knowledge and intentions. He was a true supporter of the poor and underprivileged. Yet his decisions and actions damaged the Iranian polity, society, and economy more than those of any other leader of the Islamic Republic.

A self-made man from a large working-class family with brief civil service as a provincial governor and a controversial tenure as the mayor of Tehran, he won a stunning presidential victory in 2005 trouncing four political giants, including a former two-time president and a pillar of the 1979 revolution.

This darkest of all dark horses managed to win another term in 2009, defeating a former wartime prime minister and a former speaker of the Majlis. The second victory, however, was marred by widespread accusations of vote-rigging and fraud. Massive street demonstrations protesting his election resulted in bloodshed, incarceration of peaceful protesters and the house arrest of his two main rivals. Facing this havoc, he still struck an arrogant, defiant and combative attitude, calling the protesters "weeds and debris." His second term also turned out to be crisis-ridden as he tangled openly with the Majlis speaker and the judiciary chief, was overridden by the supreme leader on several occasions, and steadily lost the full support of conservative Majlis deputies and hard-line newspapers. 
As it ultimately turned out, he was the wrong man for the job. He lacked the proper dignity and maturity to handle his position, mismanaged the country's delicate and vulnerable economy, and adopted a needlessly belligerent and defiant position toward the West.

\section{PERSONAL VALUES}

As a product of hard-scrabble roots and a self-styled crusader for the poor and the disenfranchised, Ahmadinejad perceived economics as a handbook for distributing assets and income rather than primarily a source of income and wealth creation. A pious Muslim, he rejected all non-Islamic economic systems - capitalism, socialism and communism — as unjust, exploitative and oppressive. Consequently, he found the current personal and regional distribution of wealth and income in the global as well as the Iranian economy unfair, unjust and distorted. He also harbored an irrational personal and ideological grudge against banks and bankers, wishing to abolish interest payments and encourage non-interest banking institutions (Qarzol-Hassaneh). He distrusted big business, favoring small production units. He regarded inflation a result of higher production costs rather than a monetary phenomenon. Believing money to be the answer to every social and economic problem, he undertook an unprecedented expansionary monetary policy. He believed that the reform and reconstruction measures undertaken by his two predecessors had benefited some privileged segments of society and bypassed the masses. In particular, he thought that the oil money had been unjustly distributed. An ardent Iranian chauvinist and an Islamic zealot, he believed that the West's "geopolitical hegemony" (called "arrogance" in the Islamic
Republic's lexicon) has to be challenged for both political and religious reasons.

Having caused a sea change in Iranian politics by besting four better-known, more experienced, more attractive, more qualified and more promising contenders, he was naturally expected to show a certain humility and to exhibit respect for the defeated elders and a willingness to consult with them. Instead, he took a defiant, condescending and dismissive attitude, repeatedly bragging about his more than 20 million votes and claiming to have a mandate for drastic change.

\section{MANAGEMENT STYLE}

As a political neophyte with little managerial knowledge or experience but a huge ego and unbounded self-confidence, he confronted his formidable presidential tasks with a naive abandon. He adopted an informal, down-to-earth manner but micromanaged behavior, often in clear violation of statutory requirements. Convening cabinet meetings periodically in all of the country's 31 ostans (provinces), making hundreds of personal trips to different cities, answering millions of petitions from the rank and file, approving thousands of small development projects on the spot during his provincial trips exemplify his populist style.

Arbitrary selection of staff and bureaucratic cadres was another hallmark of his administration. Instead of considering expertise, experience and professional qualifications as criteria for choosing the government's top officers, he chose professional affinity, personal loyalty and total obedience. True to form, he methodically dismissed the technocrats assembled by his two predecessors and replaced them by commanders from the Islamic Revolution Guard Corp (IRGC) and the Basij militia. 
At one time, 12 of his 18 -member cabinet were from these two organizations; and when his administration ended, six ministers were still former military and security officers. By one estimate, the share of the IRGC in the economy increased 10 times during his tenure.

Adulation was his second major criterion for personnel selection. For example, a mid-level functionary who described him as "the third century's miracle-maker," and his maskan-e-mehr housing project as "the finest undertaking since Adam," " was promoted to first vice president. A director of Iran's Tourist Organization who called him "Iran's golden opportunity," whose "audacity has now become universally recognized" became his chief of staff and number-one adviser. A professor in one of Iran's third-rate universities was made a cabinet minister, as he had supervised the president's doctoral thesis on traffic management.

Ahmadinejad's dictatorial tendencies were another hallmark of his eight-year administration. Unquestioned acceptance of his decisions and faithful execution of his orders were prerequisites for holding major state positions. Failure resulted in quick dismissal. ${ }^{3} \mathrm{~A}$ score of administrative and economic councils in charge of auxiliary decision making were dismembered in the first few months of his administration. And, most significantly, the Planning and Budget Organization, the purveyor of Iran's five-year development plans and preparation of fiscal budgets, was abolished and its duties transferred to the president's office.

Issuing ministerial decrees contrary to established Majlis statutes, refusing to execute legislation, hasty and ad hoc decisions with no prior preparation (e.g., approving some100 small projects in two hours on one of his provincial trips) and other such actions demonstrate his governing style. ${ }^{4}$ One of his dismissed cabinet ministers describes him as an egotist who dismisses his critics, feels answerable to no one, places blame on others and belittles everyone around him.

$\mathrm{He}$ and his disciples have frequently bragged about his international reputation. One of his ardent devotees has called him "a unique and incomparable global leader." He himself once said about his trips to various countries, "Everyone is eager to hear the Iranian people's message. The world is rapidly becoming Ahmadinejadized." ${ }^{6}$ In a sense, no head of a government of the size and significance of Iran has been so well-known and talked about around the globe. He was the butt of jokes on late-night American comedy shows and a gift from heaven to cartoonists.

\section{ECONOMIC APPROACH}

With the exception of Ahmadinejad himself and his small circle of friends and admirers, there is no analyst inside or outside of Iran who does not believe that the Iranian economy was grossly mismanaged, if not permanently damaged, during his administration. The extent and dimensions of this mismanagement, however, are hard to assess due to the official data that is deliberately withheld, camouflaged, doctored, falsified or contradicted by the agencies involved. ${ }^{7} \mathrm{~A}$ recent report by the Majlis' Research Center refers to most of the 2005-13 official data as defective and misleading. ${ }^{8}$ A Majlis deputy has asked for an independent governmental commission to review all data presented by the administration. ${ }^{9}$

After publishing cryptic and questionable data on basic economic indicators in his first term, the administration stopped 
releasing figures in 2008 on national income (GDP growth). Figures on inflation and unemployment released by the Central Bank and the Statistical Center have been contradictory and dubious. Figures on foreign-exchange reserves are labeled "confidential" and not published. Budget deficits are routinely camouflaged by counting borrowing as revenue. Due to these shortcomings, all arguments and conclusions made here must be treated with caution and subject to necessary correction.

Ahmadinejad's eight-year economic record may be said to represent the soul of his presidency. He began his tenure with lofty rhetoric. Slave to unnecessary details, the new president initially announced four transcendental values, fourteen basic objectives, and 58 specific proposals to improve the Iranian economy, the main popular concern. ${ }^{10}$ True to his campaign promises, these values included justice, empathy, service to people, and improvements in the country's material and spiritual conditions. The main objectives, however, included essentially justice: fighting against poverty, corruption, discrimination and nepotism; progressing toward an Islamic society; and observing justice, peace and dignity in international relations.

His repeated slogans of "justice, compassion, fairness and integrity" promising fair income and wealth distribution, increasing economic opportunities, and fighting corruption were welcome by a large segment of the population. Passing as a champion of the poor and working classes, he called himself the people's "servant" (nokar) and defender of the "oppressed" (mazloom); both words signify a humbler and sharper connotation in Persian. He specifically promised to fight the "oil mafia," put oil money on everyone's dinner table, restore full employment within two years, and reduce the size of government.

A confessed economic illiterate and proud of it, he once said, "Thank God that I do not know about economics." $11 \mathrm{He}$ embarked on a number of misguided policies, ignoring all advice from independent economists and relying on his personal and ideological tendencies. Influenced perhaps by his austere childhood and regarding money as the key to every economic problem, he began with a highly expansionary program: increasing the fiscal budget, revving up the Central Bank's printing press, expanding bank lending, and removing every administrative barrier to his plans. He dismissed several Central Bank governors who abstained from monetizing the government's debt. According to a newspaper report, some 500 trillion rials were printed and put into circulation during Ahmadinejad's tenure. ${ }^{12}$ At the same time, the government debt to the banks and the private sector during his tenure reached 1,800 trillion rials ( $\$ 72$ billion). ${ }^{13}$

The annual budget went up 5 percent above the inflation rate, from $1,590,000$ billion rials in 2005 to 7,280,000 billion in 2013 - 4.5 times — with a deficit every year. Corresponding total liquidity in- 
creased from 92,000 billion rials to 5,300 billion -5.75 times. During the same period, the state sector's debt to the banking system went up from 236 trillion rials to 1152 trillion. A fortuitous rise in oil-export receipts gave his administration some $\$ 700$ billion - compared to $\$ 440$ billion received by all previous administrations since the revolution, and five times the receipts between the discovery of oil in 1906 and the end of the Pahlavi regime in 1979.

Faced with protracted double-digit price rises from perennial budget deficits and rising debt to the banking system, Ahmadinejad decided to combat this demandcaused economic disequilibrium by focusing on the supply side. Thus, instead of trying to raise revenues or reduce wasteful expenditures, he chose a crowd-pleasing, short-term policy of controlling costs, with scant regard for its harmful long-term implications. To keep household and business expenses in check, the government proceeded to hold three vital cost factors - exchange rates, interest rates and basic energy prices - in check through government diktats. The outcome was a near disaster in all three areas.

Regarding a strong national currency as a symbol of affluence and prestige, the president pushed to keep the Iranian rial artificially high against the U.S. dollar and other foreign exchange when every economic indicator required the opposite policy. Keeping the exchange rate artificially overvalued in order to hold import costs down led to a number of troublesome consequences: (a) reducing domestic producers' ability to compete with foreign suppliers; (b) bringing down domestic production capacity of import-competing industries by some 30-40 percent; (c) idling thousands of workers with each additional billion dollars of imports; (d) worsening
Iran's non-oil trade balance; and (e) giving a hefty subsidy to foreign farmers and manufacturers. The over-valued exchange rate also resulted in increased national dependence on the world economy (even for essential food items) and capital flight. Thus, with the imposition of tough new sanctions on Iran's oil exports and its central bank operations, announced in late 2011, the Iranian rial lost two-thirds of its value against the dollar and other foreign exchanges. The subsequent era of exchange instability was ensured. Strangely enough, toward the end of his tenure, when the U.S. dollar value of the Iranian rial was fixed by the central bank at around 10,000 rials and the inflation-adjusted equilibrium rate was estimated to be 24,000 rials, the president wished to bring the rate down to 5,000 rials.

The government's extensive interestrate regulation and mandatory lending was the second policy mistake. Holding interest rates on savings deposits below the inflation rate and keeping bank charges on commercial and investment loans below free-market levels in the bazaar inflicted immeasurable damage to the economy. Low (and negative) returns on deposits discouraged individual savings, stifled productive investments, and led savers to move their funds from bank accounts to such outlets as real estate, precious metals and U.S. dollars. Losing savings deposits led the commercial banks to steadily borrow from the Central Bank for their voluntary as well as state-mandated loans. As a result, commercial bank debt to the Central Bank rose more than 13 times. ${ }^{14}$

Government-dictated loans to favored, but money-losing, projects have been a main cause of the banks' skyrocketing nonperforming assets - from a mere 70 trillion rials in 2005 to 700 trillion rials in 2013. Sizeable differences between 
mandated bank interest rates and the rates prevailing in the bazaar, combined with the small penalty for late repayments of loans, induced some well-connected businessmen to borrow money from the state banks at rates in the low $20 \mathrm{~s}$, lend the borrowed sum in the bazaar at percent rates in the $30 \mathrm{~s}$, and postpone repayment of the loans for years at an annual penalty of only 6 percent! Poor and unprofessional assessments of borrowers' proposed projects and the concentration of bank loans on a few selected megaborrowers were other causes of the banking system's problems. Nearly 8 percent of total bank loans are now reportedly in the hands of less than 12 percent of active businessmen.

Keeping energy prices artificially down for years resulted in profligate energy consumption, the continuation of energy inefficiencies, the rise of energyintensive industries vulnerable to external shocks, and a growing need for energy imports, severe air pollution and a clear rise in energy smuggling to neighboring countries.

The outcome of this rank mismanagement has been well reflected in the behavior of the main economic indicators. The GDP growth of 6.9 percent in 2005 gradually tapered off year after year, ending the last two years of Ahmadinejad administration (2011 and 2012) in negative territory, at minus 1.7 percent and minus 5.4 percent, respectively, ${ }^{15}$ for an average annual growth of 3 percent during the whole period. Even this modest growth was achieved at a very high cost. For each 1 percent of growth during the Khatami administration, the government had invested $\$ 5.4$ billion, ${ }^{16}$ while the Ahmadinejad administration spent $\$ 8.2$ billion.

Data on various aspects of employment (and unemployment) are among the least comprehensive and reliable published by the administration. The official unemployment rate reportedly rose from 11.5 percent in 2005 to 12.2 percent in 2013, with more than 3 million people out of jobs. The figure for the 15-24 age group was at the critical level of 27 percent. Unofficial figures indicate 20 percent of the total labor force looking for work; with 5 million youth entering the job market now, the country will soon be faced with 8 million seeking employment. Official figures from the Statistical Center further show that participation in the labor force declined from 41 percent in 2005 to 37.3 percent in 2012 . In short, only about 68,000 jobs were created each year from 2005 to 2012; about 34,000 annually have been added to the unemployed. ${ }^{17}$ Despite the president's officially expressed sentiment regarding women (e.g., the first president to nominate three women for his cabinet), women's participation in the labor force was at best 17 percent. Female unemployment actually doubled during the period, in addition to women's being subject to discrimination in wages, promotion and tenure.

The official consumer-price index of 10.4 percent in 2005 began to rise steadily year after year, surpassing 40 percent the world's third highest - in the summer of 2013, when Ahmadinejad's term ended. Private estimates of the price rise were consistently higher. Significantly responsible for the steady rise in liquidity and consumer prices were the president's three signature projects - financed primarily by the Central Bank's new money creation: (1) loans to the so-called "quick returns" projects to create 2 million jobs, (2) lowcost housing in the periphery of large cities, and (3) the controversial cash-payment-based subsidies reform. ${ }^{18}$ All three are considered failed schemes. The hous- 
ing project alone, according to the current housing minister, has been responsible for 40 percent of the new liquidity.

To combat inflation, instead of balancing the budget, reducing bank lending and controlling liquidity, Ahmadinejad opened the import gates for cheaper competing products. Thus, of the nearly $\$ 700$ billion in oil-export revenue received during his eight-year tenure -63 percent of all oil income during the last

\section{By being combative and provocative, and} by repeatedly denying the Holocaust, he raised the ire of the civilized world and made it impossible for the Islamic Republic to pursue a serious foreign policy.

108 years - some $\$ 440$ billion was spent on imports, raising yearly purchases from $\$ 36$ billion to $\$ 60$ billion. The outcome, while benefiting low-income groups by decreasing prices, was the destruction of domestic industries. At the same time, precious foreign exchange received from the export of a depleting resource, instead if being reinvested to produce new wealth, was squandered in the import of petty consumer goods.

The government claims that, as a result of its populist projects, the Gini coefficient of income distribution improved. Although denied by other reports, even if it were true, relative poverty did not diminish, and still over 20 percent of the population languished in poverty.

On top of these policy errors, Iran's economy experienced a sea change during Ahmadinejad's tenure in the direction of economic militarization - comparable to the Indonesian and Egyptian cases. Already suffering from a large and inefficient state sector, it moved further in that direction, despite earlier promises to reduce it. Initiated and supported by Ahmadinejad himself, the Islamic Republic's Guardian
Corps (IRGC) rapidly took over an increasing segment of the Iranian economy. The Khatamol-Anbia Corporation, and its sister, Khatamol-Ossia, the engineering arms of the IRGC, gradually became the largest and richest domestic contractors, spreading their wings over such sectors as oil, gas, petrochemicals, industry, mines, road building, irrigation and dam construction, Curiously enough, as the UN, U.S. and EU economic sanctions primarily targeted the Corps, they all inadvertently helped it to grow by overtaking the work of foreign contractors and by becoming the contry's number-one smuggler.

And, despite frequent promises to reduce government's role in the economy, and the budget's reliance on oil revenues, the opposite occurred in both cases.

Recent information shows that the muchtrumpeted program of privatization during Ahmadinejad's tenure was really a sham: only 17 percent of the state enterprises were sold to the true private sector, and 83 percent were taken over by the semi-public agencies. ${ }^{19}$

\section{FOREIGN RELATIONS}

In the foreign arena, just as Western frustration with the slow pace of negotiations on Iran's nuclear program was building, and the Islamic Republic needed an experienced and astute leader to handle the situation, the opposite occurred. A narrowminded Islamic fanatic, who had never traveled outside Iran and was reflexively anti-Western, took the helm. Although not directly involved in the conduct of nuclear 
negotiations with the $\mathrm{P} 5+1$ group, his attitudes inflicted irreparable damage to Iran's position. By being combative and provocative, and by repeatedly denying the Holocaust, he raised the ire of the civilized world and made it impossible for the Islamic Republic to pursue a serious foreign policy. Oddly enough, toward the end of his tenure, he called his blatantly and damaging statement about Holocaust one of the "greatest achievements of his presidency"; he had raised "a taboo topic that no one in the West allowed to be heard" and thus "broke the spine of the Western capitalist regime"' 20

Enormously ambitious and highly self-confident, though a novice in diplomacy and foreign policy, Ahmadinejad lowered the international prestige of Iran had gained during the Khatami administration. He forged an unholy alliance with a number of small, poor and wayward countries in Latin America and Africa against Washington, further contributing to Iran's isolation and negative image. His fruitless confrontational pronouncements caused Iran's national interest irreparable damage. And, by assuming the role of Western "provocateur-in-chief" pursuing confrontation with Washington, the European Union and the United Nations, ${ }^{21}$ he triggered one economic sanction after another, undermined Iran's global standing, and ultimately turned it into a pariah state. Meaningless statements like "we do not need the world, the world needs us" caused nothing but problems. Iran's relations with Bahrain, Yemen, Lebanon, and Saudi Arabia badly deteriorated due to Tehran's support of Shia minorities in those countries.

\section{A SUI GENERIS PHENOMENON}

By all indications, Ahmadinejad is intelligent, informed and politically astute. He often brags about his advanced edu- cation and his doctorate. He writes and speaks eloquently in Farsi. He is a master in debate. ${ }^{22}$ Yet some of his statements and proposed projects not only defy explanation, ${ }^{23}$ but also smack of delusion:

- The Holocaust did not happen; it was a pretext by Western governments to justify the establishment of the Zionist regime.

- The September 11 tragedy in Washington and New York was orchestrated by Washington to combat U.S. economic recession, a fact accepted by the majority of American people and most nations around the world.

- The west created HIV in order to plunder Africa.

- Our Western enemies are preventing rain-bearing clouds from coming our way, causing draught.

- One of our 13-year-old students has been able to generate nuclear power in her basement. We have a sorcerer who, getting inspiration from the saints, can point to various mines by looking at the grass.

Equally astonishing have been some of his pet proposals. In a country with scant rainfall, frequent drought and water rationing, he proposed to give every citizen 2,000 meters of land for a vegetable garden to grow vegetables and sustain himself. When he was reminded of the paucity of water for such a venture, he said, "God never created a land without enough water for it!" In a country already importing 30 percent of its food, he proposed that Iran's prize-winning population-control program be abandoned and that the government encourage every family to have four to six children, as the country could afford to sustain 150 million people. 


\section{A SORROWFUL FINISH}

Ahmadinejad's administration came to an end without even a whisper. There were no celebratory parties, no appreciative demonstrations, no praise of his tenure. Members of the new government have taken turns pointing out his misdeeds. At a birthday party organized for him a few weeks after leaving office, only 70 people showed up. He has shunned public speaking since then. The only faint praise of his services has come from Supreme Leader Khamenei, who had backed him all along and found the ex-president's ideas close to his own. At the last meeting of his cabinet with the Rahbar in mid-July 2013, Ayatol- lah Khamenei did praise his government for its "accomplishments," particularly for propagating and illuminating "revolutionary slogans. ${ }^{24}$

Ahmadinejad's spectacular fall from grace is best portrayed in his treatment at the hands of the most conservative newspaper, Kayhan, which normally reflects the views of the supreme leader. The lead editorial, which had initially labeled his administration "the most beloved government" since the Islamic revolution, changed its tune. On Tuesday, April, 23, 2013 , it called the outgoing president "a coward, a bluffer and insincere."

\footnotetext{
${ }^{1}$ Kayhan (London), July 17, 2013.

${ }^{2}$ Kayhan, May 8, 2013.

${ }^{3}$ www.radiofarda.com, August 3, 2013.

${ }^{4}$ A long list of specific examples may be found in Radio Farda's Persian broadcast, August 3, 2013

${ }^{5}$ Kayhan, May 8, 2013.

${ }^{6}$ Inter Press Service News Agency, November 30, 2006.

${ }^{7}$ www.jomhourieslami.com, September 21, 2013.

${ }^{8}$ www.jomhourieslami.com, August 30, 2013.

${ }^{9}$ www.radiofarda.com, July 22, 2013.

${ }^{10}$ For the full list, see Iran Economics, September 2005.

${ }^{11}$ Vision of the Islamic Republic of Iran Network (TV) August 14, 2006.

${ }^{12}$ www.radiofarda.com, October 4, 2013.

${ }^{13} \mathrm{http}$ ://payvand.com, October 23,2013.

${ }^{14}$ www.radiofarda.com, October 24, 2013.

15 www.radiofarda.com, September 7, 2013.

${ }^{16}$ www.jomhourieslami.com, October 14, 2013.

${ }^{17}$ www.radiofarda.com,September 28, 2013.

${ }^{18}$ For detailed discussions of this program, see Middle East Economic Survey, May 31, 2010, June 20, 2011, January 30, 2012, and December 14, 2012.

${ }^{19}$ www.jomhourieslami.com, November 7, 2013.

${ }^{20}$ Speech quoted in Iran Times (Washington), July 12, 2013.

${ }^{21}$ His reckless rhetoric denying the Holocaust and casting doubts about the perpetrators of the September 11 attack induced Washington to marshal a universal condemnation of Iran's position.

${ }^{22}$ For a fuller description of his character, see Jahangir Amuzegar, "The Ahmadinejad Era," Journal of International Affairs 60, no. 2 (March 2007).

${ }^{23}$ For a list of these and similar statements, see radiofarda.com, April 202013.

${ }^{24}$ www.radiofarda.com August 1, 2013.
} 